\title{
Islamic Versus Conventional Banks in Lebanon: An Empirical Study of Credit Risk Management
}

\author{
Boutheina Hachem $^{1} \&$ Hiyam Sujud ${ }^{1}$ \\ ${ }^{1}$ Finance Department, Faculty of Business, Lebanese University, Lebanon \\ Correspondence: Boutheina Hachem, Finance Department, Faculty of Business, Lebanese University, 1st Branch, \\ Lebanon. Tel: 961-373-1502. E-mail: boutheinahachem@gmail.com
}

Received: May 17, 2018

doi:10.5539/ijef.v10n8p53
Accepted: June 15, 2018

Online Published: June 30, 2018

URL: https://doi.org/10.5539/ijef.v10n8p53

\begin{abstract}
The aim of this research is to compare conventional and Islamic banks in various aspects of credit risk management processes. The study used 200 questionnaires, collected from 21 traditional banks and 4 Islamic banks in Lebanon. The results found that differences in the various issues of credit management between Islamic and conventional banks. Islamic banks are more understanding, aware, and cautious in their approach than traditional banks. Islamic banks are more efficient in assessing and analyzing credit risk than conventional banks. Lastly, Islamic banks are more used to credit risk mitigation than traditional banks.
\end{abstract}

Keywords: credit risk management, conventional banks, Islamic banks

\section{Introduction}

The banking industry has seen significant progress in technological developments, communications, globalization of the economy, and the liberalization of financial markets, all of which have led to increased competition among banking institutions and increased risks to their existence and sustainability.

Today, all financial institutions in the world have claimed that they are a risky business and that banks has become a competitor by applying effective risk management techniques. Commercial banks and financial institutions contribute to the process of economic growth by mobilizing financial resources and providing them to individuals and business sectors, thus balancing savings and investment resources. Bank credit is one of the most important activities of any banks. In the absence of such activity, it loses its primary function as a financial intermediary. Consequently, banks cease to exist. In addition, the return of credit activity is the main focus of banks' activities (Greuning \& Bratanvic, 2003; Richard et al., 2008). However, the function of commercial banks as intermediaries creates different types of risks and at different volumes reflected in the performance of these banks (Gestel \& Baesens, 2009).

Credit risk is the most important component of commercial banking risk (Abou Hussain \& Al-Ajmi, 2012) which contributes to more than $50 \%$ of the total banking risk components. In addition, more than $80 \%$ of the balance sheet items are related to these risks (Hennie, 2003). Thus, it is the most common risk faced by Islamic banks, as their activities are dominated by debt-like transactions.

Credit risk refers to the risk that a party to the contract (debtor) will fail to meet his financial obligations in accordance with the agreed terms (Jachi, Izhar, Omar, \& Apostolik, 2015). These risks are likely to lead to bank losses (Bo et al., 2005) but many researchers believe that they are the main cause of the banking crises that have suffered and suffer from developed and developing countries in recent economic crises (Hakness \& Schnabel, 2010; Mileris, 2012; Romanova, 2012).

\section{Problem Statement}

It should be noted that credit is the cornerstone of banking business and is the main activity of banks, and from it comes the bulk of its profits, and therefore the risk of credit portfolios arises from bank-lending operations, where these risks begin to emerge from the credit progress stage and increase with subsequent phases, especially if the credit risk management criteria is weak and incomplete (Brown, 1998; Richard et al., 2008). Consequently, Islamic banks, as well as conventional banks, have given considerable attention to credit risk management, especially after the credit crisis of 2008 that led to the collapse of many international banks. 
The Basel Committee recognized the impact of credit risk on banks and called for a clear mechanism to manage these risks, enabling them to adopt Basel I agreement in 1988, Basel II in 2004, and finally the Basel III.

However, the distinctive nature of the credit operations in Islamic banks has allowed them to go beyond the conventional banking regulations and limits, which led to the opening up of two types of risks, the risks inherent in the traditional nature of the banking business, and the uniqueness of them as a result of the approach followed to perform its activity; thus the Islamic banks search for methods and ways of hedging are different from the traditional models which do not serve the nature of its work.

The operations of Islamic banks are based on the principles of Islamic law and the prohibition of riba and illegal speculation. In contrast, they call for the sharing of risks, i.e. participation in profit and loss, which distinguishes them from traditional banks (Ahmad \& Hylmun, 2015).

Islamic economists are working hard to develop types of loans for Islamic banks based on Shariah principles and similar to conventional banks to replace interest payments. Therefore, Islamic financial institutions may be exposed to more risks than conventional financial institutions due to a number of reasons including the specific nature of risks and the non-specific financing methods of projects, whether profit-and-loss sharing, or contract. The absence of a standard for each type of contract is another element in making Islamic banks are more risky than traditional banks (Sundararajan \& Errico, 2002). Islamic financial institutions are expected to impose risks on the financial system that differ in many respects from those imposed by the traditional financial system.

Through the above can be raised the following problem:

What is the distinctive nature of credit risk management in Islamic banks versus those in conventional banks?

\section{Significance of the Study}

The issue of credit risk management is one of the most important research topics, especially after the global financial crisis, where many experts, in the traditional and Islamic banking world, were involved.

Credit risk is defined as the probability that the debtor will be unable to meet contractual obligations and pay the required amount (Jachi, Izhar, Omar, \& Apostolik, 2015). Credit risk can occur in all instruments or products offered by banks; the only difference is the degree to which banks are exposed to and how to mitigate them.

The importance of credit risk management in banks is as follows:

Credit risk is the biggest threat to conventional banks and Islamic banks alike, especially as they are faced with the extent of their financing and financial operations. The conventional banks face this type of risk in the amount of their operations because the relationship between these banks and their customers is the relationship between any creditor and debtor, e.g. lending activities are a credit risk. Islamic banks face this type of risk in the form of financing based on contracts such as Murabaha, Salam, Istisna and Ijara, based on contracts of participation. For Islamic banks, each type of contract leads to credit risk to the bank's profitability.

\section{Objectives of the Study}

Banks need a deep understanding of the basics of credit risk and the procedures available for their analysis and administration. Credit risk management is the main key of bank profitability. Financial rights have a limited positive yield and significant inadequacy risk. By declining credit losses, banks can progress returns to shareholders.

Credit risk measurement is a crucial part of the risk administration process. By rational measuring of credit risk, the bank can (1) better evaluate whether credit will be provided to the customer under any circumstances; (2) improve portfolio adjusted risk returns; (3) properly allocate the expected losses; and (4) ensuring the suitability of the capital (Jachi, Izhar, Omar, \& Apostolik, 2015).

There is a difference between conventional and Islamic banks in all these aspects. This is because conventional banks operate with interest rates system while Islamic banks operate with profit-sharing system. As a result, the concept of risk in the Islamic financial system differs from that in the traditional financial system. The Islamic financial system is seen to be compromised by two dimensions of "uncertainty" and freedom of contract. Gharar in Islamic law is an element of the opportunity to contain asymmetric information, uncertainty, risk, or even speculation, and any result and profit that is illegal, and is excluded according to the Islamic law. This is not the case in the traditional banking system. In conventional banks, depositors have a fixed claim on assets to banks according to the predetermined interest rate plus return on capital. Traditional banks, therefore, carry out their commitment to depositors irrespective of their profitability. In contrast, Islamic banks regulate the principle of risk sharing. Commercial and Islamic banks should therefore develop ways to ensure credit risk assessment to avoid mis-choice and avoid moral hazards. 
Recognizing the importance of credit risk, this study aims to do the following:

1) Comparison of understanding and awareness of credit departments of credit risk between conventional and Islamic banks in Lebanon.

2) Comparison of credit risk assessment and analysis of credit departments between traditional and Islamic banks in Lebanon.

3) Comparison of the practices of credit departments to mitigate credit risk in conventional and Islamic banks in Lebanon.

4) Suggest proper recommendations based on the study results that help credit departments to improve the weaknesses in credit risk administration in Lebanese banks.

\section{Research Hypotheses}

Credit risk management in Islamic banks is more complex due to some additional disadvantages. The defaulting may occur if the debtor is incapable or reluctant to pay the full amount of the debt. Under certain conditions, the debtor may not be able to fulfill the terms of the contract for reasons beyond his control. By contrast, under different conditions, a debtor with adequate income may select not to meet his debt commitment. In practice, the main reasons for not meeting the terms of a debt-like contract in commercial dissimilarities are the validity or necessities of the contract, and the absence of penalty fees for late payment (or delay in delivery as in the case of salam contracts) as in conventional banks. This restriction can be used badly by the counterparty and may deliberately delay the payment as they know that the Islamic banks will not charge them anything. Khan and Habib (2003) believe that for Islamic banks, the risk of default counterparty is the most important risk and the absence of any default treatment except liquidation and administrative procedures that do not compensate the bank.

Islamic financial institutions are expected to adopt a more effective credit risk management than those imposed by the traditional financial system. Because the loss to the Islamic banks due to mismanagement of credit risk will eventually turn to depositors.

Therefore, the hypotheses of the study were formulated in pessimistic form as follows:

The first hypothesis: There are no significant differences in understanding and awareness of credit risk between Islamic banks and conventional banks.

The second hypothesis: There are no significant differences in credit risk assessment and analysis between Islamic banks and conventional banks.

The third hypothesis: There are no significant differences in the level of use of credit risk mitigation methods between Islamic banks and conventional banks.

\section{Literature Review}

We could say that credit risk is the risk that borrowers will fail to meet their obligations to the bank when these obligations are due or thereafter or non-payment under the agreed terms, i.e., that these risks are related to the counterparty in the contract in terms of its ability to pay its obligations to the bank at the agreed time and date.

Although conventional and Islamic banks offer similar services and products such as deposit accounts, various types of financing, credit cards and mortgages, the products of Islamic banks are based on the concept of sharing profit and loss. Thus, the risk of Islamic banks, like other financial institutions, is one of the main challenges for these banks, which requires creating a suitable environment for managing these risks (Ellul \& Yerramilli, 2011; Ouamar, 2013). This may have prompted Basel 1999 to direct the boards of directors to stimulate credit, strategy and senior management policy to do so, and the need to ensure the integrity of the process of providing and granting credit through the establishment of clear criteria for granting credit; and maintaining appropriate credit management for the credit portfolio in the light of measurement and control and ensuring adequate risk control.

Many researchers have investigated the credit risk in Islamic banks as well as in conventional banks. In their views, Islamic banks not only face the risks faced by conventional banks but must deal with the risks arising from their unique asset and liability structure and compliance with Shariah requirements, exposing them to specific risks related to each type of contract. Islamic financial institutions are therefore expected to impose risks on the financial system that differ in many respects from those imposed by the traditional financial system.

This has led many researchers to believe that Islamic financial institutions can be exposed to risk more than traditional financial institutions due to several reasons including the nature of risks and the non-specific financing methods used to finance the project, whether through profit-sharing or contracts (Sundararajan \& 
Errico, 2002; Venardos, 2006).

A study in Bahrain (Hussain \& Al-Ajmi, 2012) found that Islamic banks face higher risk than traditional banks, and that understanding and management of risks are much different from conventional ones. This conclusion was confirmed by a study in Malaysia (Tafri et al., 2011) which found that there is a big difference between traditional and Islamic banks in the market value of risk, ways of mitigating credit risk, and operational risk management tools.

However, some believe that both types of banks are exposed to similar major banking risks (Hussain \& Al-Ajmi, 2012) and risk management frameworks. (Hassan, 2009; Iqbal \& Mirakhor, 2011).

There are several studies on credit risk management, of which a study done by Abusharbeh 2014 that examined the impact of Islamic financing modes and credit risk on future profits in Indonesian Islamic banks. The study aimed to find a relationship between Islamic financing methods, bad financing and the profitability of Islamic banks. The results of the study showed that equity financing has a significant positive correlation with non-performing finance. Accordingly, this indicates that Indonesian Islamic banks have a conservative policy towards participating in equity financing, in order to ensure low risk and provide a high level of liquidity.

Moreover, the study found that Murabaha financing has a positive relationship with future profits. This means that Indonesian Islamic banks prefer to finance their investment projects using debt financing instruments and risk aversion.

Melhem's study (2013) attempted to measure the credit risk at Arab Islamic International Bank and its management methods. The study found that the credit risk in 2009 and 2010 in Arab Islamic International Bank increased due to the high level of default in these two years. The Bank was unable to deal with these debts as conventional banks do in 2007, 2008, and 2011.

Omar's study (Omar et al., 2012) aimed to compare Islamic and non-Islamic banks in the United Arab Emirates (UAE) in the management of credit risk. The study used a methodology based on a field study to collect data. A sample of six commercial banks from the United Arab Emirates was formed with three non-Islamic banks and three Islamic banks with 148 credit risk managers. The study also examined the factors that distinguish between Islamic and non-Islamic banks in the UAE. The study found that managers in Islamic banks now rely not only on personal experience and simple credit risk analysis, but also develop and practice new technologies as well as traditional ways of managing credit risk, compared to non-Islamic banks of the improvement in credit risk management.

In the same context, a study (Kabir et al., 2014) was aimed at testing whether Islamic banks and conventional banks have different levels of credit risk. Using the Merton model, a market-based credit risk measures the credit risk of 156 conventional banks and 37 Islamic banks in 13 countries, assessed between 2000 and 2012. The study concluded that credit risk in Islamic banks is much lower than conventional banks when measuring credit risk on the Merton model. In contrast, as expected, Islamic banks bear much higher credit risk when using Z-scale. In general, the results indicate that the methodology used plays an important role in assessing the credit risk of Islamic banks.

Rauch and Imbierowicz (2014) studied the correlation between credit risk and liquidity in conventional banks, using a sample of US banks over the period (1998-2010). The study recognized that both credit risk and liquidity have a significant effect on the possibility of bank default. They also concluded that given the fact with no direct correlation between liquidity and credit risk, the relationship between these two types of risk rises the possibility of bank default.

\section{Methodology}

This section presents the methods for collecting and analyzing data used in the study. The section describes research design, population study, sample size, methods of data collection, research techniques, data analysis, and presentation of results, among others.

The research design used the descriptive survey in this study to collect data from various resources. To achieve the purpose of the study, the following tasks were carried out:

- Based on the purpose of the study which is to compare credit risk management practices between conventional banks and Islamic banks in Lebanon, a comprehensive review of the latest available literature on the comparison of credit risk management practices between conventional banks and Islamic banks in Lebanon was conducted.

- Identify a set of actions or practices that will be most appropriate for this study. 
- A pilot survey was performed.

\subsection{Sample Selection}

The study sample consists of senior employees in credit management departments in both Islamic and conventional banks in Lebanon, which work, operate, and analyze banking credit risk, consisting of (25) banks, including 4 Islamic banks. The sample members were classified into two groups: the sample of Islamic banks and the sample of conventional banks, with the aim of determining whether there are differences in the areas of credit risk management between Islamic and conventional banks.

Since the researchers in this study were unable, for reasons of some banks, to reach all the population, therefore were unable to select a representative sample of the actual number of banks adopting credit risk in Lebanon, they decided to use a judgmental sample consisting of a large sample size 200.

\subsection{Instrumentation}

The researchers have used the questionnaire that has already been used by former researchers, Hussain and Al-Ajmi (2012) and Hassan (2009). However, the questionnaire has been modified and adjusted to commensurate with the nature of the study.

The researchers conducted a pilot tool to test the validity and reliability of the questionnaire in data collection for the study purposes. By reviewing the literature, informal deliberations with seven selected professionals in this area were assessed and discussed to improve content and ensure the validity of the questionnaire.

Reliability was tested using the 25 questionnaires that have been tested with randomly selected credit departments staff in both Islamic and conventional banks and were not included in the final sample. The reliability of the tool means that the tool is intended to obtain the same data when re-studying using the same study tool on the same individuals under similar conditions (Sekaran \& Bougie, 2013); the goal is to avoid a biased answer. The rule suggests that $5 \%$ to $10 \%$ of the selected sample should represent the experimental test. The trial test sample was within the recommendation. The most common measure of internal consistency (reliability) is Crombach's Alpha. The researchers used the Statistical Package for Social Sciences (SPSS) program to test the reliability of the questionnaire. The results of the reliability test were produced and the Crombach's Alpha overall correlation coefficient of 0.829 indicates a high level of reliability of the questionnaire data obtained.

Various groups from conventional as well as Islamic banks in Lebanon were asked to respond to attitude items linked to credit risk management of Lebanese conventional and Islamic banks using Likert-five-point scale format. The scale determines the degree of approval of the study sample members on each of the subjects of the study tool and to convert them into quantitative data that can be measured statistically; whereby (1) means strongly agree "SA"; (2) means agree "A"; (3) means neutral "N"; (4) means disagree "D"; and (5) means strongly disagree "SD".

To determine the degree of importance of each subject of the study instrument, a measure was adopted to understand and identify the credit risk and analyze it, and in order to understand the bank's policy capacity to reduce these risks by dividing them into three levels, the score of the cutoff was calculated by dividing the difference between the highest value of the scale (5) and the lowest value (1) at the three levels, i.e. the cutoff level equals $[(5-1) / 3=1.33]$. Thus, the three levels are as follows: $(1-2.33)$ means a low degree of application, (2.34-3.67) means a medium degree of application, and (3.68-5) means a high degree of application.

Two hundred and ninety (290) questionnaires were distributed to banks' credit risk management departments and senior employees who were randomly selected from conventional and Islamic banks. Only 212 questionnaires were returned, which is approximately a $94 \%$ response, a rate that is regarded as highly accepted by researchers.

Due to missing data, the questionnaire revealed the need to neglect ten cases in the analysis, because some respondents ignored some of the questions. Thus, we end up with 202 important questionnaires; however, we have analyzed 200 questionnaires.

The questionnaire consists of three parts.

Part I: Introduction

Part II: It consists of demographic data collected from the sample of the study and contains four closed-ended questions: (1) age, (2) qualification, (3) career status, and (4) experience in banks.

Part III: It contains three subjects concerning credit risk management in Lebanese conventional and Islamic banks. 
A. First subject measures the understanding level of credit risk management with regards to the credit risk management practices in the bank and consists of Q1 through Q4.

B. Second subject measures the level of practice of credit risk analysis adopted in the bank and consists of Q5 through Q12.

C. Third subject relates to the credit risk mitigation methods adopted in the bank and consists of Q13 through Q19.

\section{Findings and Analysis}

\subsection{Sample Demographics}

This paragraph describes the general characteristics of the respondents in terms of age, qualifications, career status, and the number of years of experience in the bank.

\subsection{Age Groups}

The results of Table 1 show that the majority of respondents were over the age of 36 years with most of them (39\%) were between 36 and 45 years old. The rest of respondents (17\%) were between 26 and 35 years old. There were only a few who were over 55 years old which is commensurate with the workforce of many banks. This is due to the reorganization of staff arrangements, in which older employees are usually retired either through the early retirement or through the voluntary retirement program.

Table 1. Age of respondents

\begin{tabular}{cccccc}
\hline Age & $26-35$ & $36-45$ & $46-55$ & Above 55 & Total \\
\hline Frequent & 34 & 78 & 56 & 32 & 200 \\
Percent & 17 & 39 & 28 & 16 & 100 \\
\hline
\end{tabular}

\subsection{Qualification}

The results of Table 2 show that the percentage of holders of bachelor's degree reached $62 \%$ and the percentage of the master's degree holders reached $74 \%$ while the percentage of holders of PHD degree is the lowest (1\%).

Table 2. Qualification of respondents

\begin{tabular}{ccccc}
\hline Qualification & Bachelor Degree & Master's Degree & PHD Degree & Total \\
\hline Frequent & 124 & 74 & 2 & 200 \\
Percent & 62 & 37 & 1 & 100 \\
\hline
\end{tabular}

\subsection{Career Status}

The results of Table 3 show that the percentage of employees at the rank of head of the Department amounted to only $6 \%$, while the proportion of customer service officer amounted to $94 \%$.

Table 3. Career status of the respondents

\begin{tabular}{cccc}
\hline Career Status & Head of Department & Customer Service Officer & Total \\
\hline Frequent & 12 & 188 & 200 \\
Percent & 6 & 94 & 100 \\
\hline
\end{tabular}

\subsection{Experience in The Banks}

The results of Table 4 show that the percentage of those with experience ranging from 1 to 5 years is only $4 \%$ while $96 \%$ of the respondents work in the banking sectors for more than 5 years.

Table 4. Respondents' experience in the banks

\begin{tabular}{ccccc}
\hline Experience & $1-5$ years & $6-10$ years & Above 10 years & Total \\
\hline Frequent & 8 & 94 & 98 & 200 \\
Percent & 4 & 47 & 49 & 100 \\
\hline
\end{tabular}




\subsection{Interpretation}

This paragraph provides the detailed statistical treatments for the questionnaires according to the questions of each subject of the three subjects (as stated in part III of questionnaire) that concerned with credit risk management in Lebanese conventional and Islamic banks as follows:

\section{A. How well do you understand and manage credit risk in Lebanese banks?}

Table 5 shows the arithmetical averages and the standard deviations of the field of understanding level and awareness of credit risk in order to calculate their importance and to rank them according to the arithmetical averages.

Table 5. Trends of the study sample on the level of understanding of credit risk management

\begin{tabular}{lcccc}
\hline Question & Mean & Std Dev & Ranking & Level \\
\hline 1. There is a common understanding of credit risk management across the bank. & 3.30 & 0.63 & 2 & average \\
2. Credit risk management is important to the Bank's performance and success & 3.82 & 0.62 & 1 & high \\
3. Accountability for credit risk management is clearly set out and understood throughout the bank. & 2.51 & 0.83 & 4 & average \\
4. Responsibility for credit risk management is clearly set out and understood throughout the bank. & 3.28 & 0.71 & 3 & average \\
5. The Bank uses complex credit risk management techniques & 2.34 & 0.77 & 5 & low \\
General Trend & $\mathbf{3 . 0 6}$ & $\mathbf{0 . 4 5}$ & - average \\
\hline
\end{tabular}

The above table shows that the trends of the study sample are of medium importance to the questions related to the level of understanding and awareness of the banks. Islamic and traditional credit risk ranged from (2.34-3.82) where the results indicate that the trends of the sample of the study is positive for all questions of the questionnaire because their arithmetic mean is greater than the default arithmetic mean (3), with the exception of question number (3) and question number (5).

This means that the members of the study sample agreed with the rest of the questions that measure the variable of understanding and awareness of credit risk. In reviewing the order of the questions, it was found that the question that states, "credit risk management is important to the bank's performance and success", came first with an average of 3.82 and a standard deviation 0.62, while the question that states "there is a common understanding of credit risk management across the bank" was ranked second with an average of 3.30 and a standard deviation of 0.63 , while the question stating "the Bank uses complex credit risk management techniques" in the last place with an average of 2.34 and a standard deviation of 0.77 compared to the general arithmetic mean.

Accordingly, the overall results indicate that there is a moderate level of understanding and awareness of Islamic banks and conventional banks of credit risk. The general arithmetic average is 3.06 and the standard deviation was low at 0.45 . This indicates convergence of opinion, in understanding and awareness of credit risk in Lebanese banks.

\section{B. What is the extent of the practice of credit risk assessment and analysis in Lebanese banks?}

Table 6 shows the arithmetical averages and the standard deviations of the practice of credit risk analysis from the point of view of the study sample members working in the credit departments of the Lebanese banks in order to calculate their importance which ranked according to the arithmetical averages.

Table 6. Trends of the study sample on the level of practice of credit risk analysis

\begin{tabular}{lcccc}
\multicolumn{1}{c}{ Question } & Mean & Std Dev & Ranking & Level \\
\hline 6. This bank assesses the likelihood of occurring credit risks. & 3.56 & 0.85 & 1 & high \\
7. Executive management regularly reviews the performance of banks in managing their & & & & average \\
credit risks. & 3.34 & 0.67 & 3 & average \\
8. Traditionally bank uses a specific analysis when it evaluates loan application. & 3.34 & 0.50 & 2 & average \\
9. When the bank evaluates a loan application, it analyses the collateral, or security put up & & & & \\
for a loan. & 3.12 & 0.87 & 4 & average \\
10. When the bank evaluates a loan application, analyses the borrower's capacity. & 3.11 & 0.80 & 5 & average \\
11. This Bank analyzes creditworthiness prior to the transaction. & 3.08 & 0.92 & 6 & average \\
12. When a bank evaluates a loan application, it analyses the character of the potential & & & & \\
borrower. & 2.86 & 0.85 & 7 & average \\
General Trend & $\mathbf{3 . 2 0}$ & $\mathbf{0 . 4 9}$ & - &
\end{tabular}


The above table shows that the trends of the study's sample are of medium importance to the questions related to the level of the practice of credit risk. Assessment and analysis in Islamic and conventional banks ranged from (2.36-3.56) where the results indicate that the trends of the sample of the study is positive for all questions of the questionnaire because their arithmetic mean is greater than the default arithmetic mean (3), with the exception of question number (12).

This means that the members of the study sample agreed with the rest of the questions that measure the variable of practice of credit risk assessment and analysis. In reviewing the order of the questions, it was found that the questions that states "This bank assesses the likelihood of occurring credit risks" ranked first with an average of 3.56 and a standard deviation of 0.85 . The question, which states that "Traditionally bank uses a specific analysis when it evaluates loan application" ranked second with an average of 3.34 and a standard deviation 0.50 , and last came the question, which states that "When a bank evaluates a loan application, it analyses the character of the potential borrower", with an average of 2.86 and a standard deviation of 0.85 .

Generally speaking, the overall results indicate that there is an average level of practice of Islamic banks and conventional banks in credit risk analysis, where the general arithmetic average is 3.20 and the standard deviation was low at 0.49 . This indicates the convergence of opinions, in credit departments in Lebanese banks about this variable.

\section{To what extent are credit risk mitigation methods used in Lebanese bank}

Table 7 shows the arithmetic averages and the standard deviations of credit risk mitigation methods from the point of view of the study sample members. In order to calculate their importance, we ranked them according to the arithmetical averages.

Table 7. Trends in the sample of the study on credit risk mitigation methods

\begin{tabular}{lcccc}
\multicolumn{1}{c}{ Question } & Mean & Std Dev & Ranking & Level \\
\hline 13. This Bank generally applies Basel II to credit management. & 3.55 & 0.92 & 1 & high \\
14. The Bank emphasizes the recruitment of qualified personnel in credit management. & 3.34 & 0.66 & 2 & average \\
15. This bank's credit risks are assessed by using quantitative analysis methods. & 2.88 & 0.65 & 4 & average \\
16. The credit department provides staff with a guide on risk management. & 3.19 & 0.93 & 3 & average \\
17. The Credit management is documenting procedures and operations. & 2.79 & 0.65 & 6 & average \\
18. This bank's credit risks are assessed by using qualitative analysis methods. & 2.86 & 0.60 & 5 & average \\
19. The Credit management encourages training programs in credit risk management. & 2.74 & 0.70 & 7 & average \\
General Trend & $\mathbf{3 . 0 5}$ & $\mathbf{0 . 5 2}$ & - & average \\
\hline
\end{tabular}

The above table shows that the trends of the sample of the study are of medium importance to the questions related to the level of risk mitigation. Techniques in Islamic and conventional banks ranged from (2.74-3.55). Where the results indicate that the trends of individuals in the study sample are positive towards some questions because their arithmetic mean is greater than the default arithmetic mean (3), and negative for some of the others, which means that the trend of the sample members of the study is between the approval and not.

In general, the overall results indicate that by reviewing the order of questions, it was found that the question of "This Bank generally applies Basel II to credit management" was ranked first with an average of 3.55 and a standard deviation of 0.92 . While the question that "The Bank emphasizes the recruitment of qualified personnel in credit management" was ranked second with an average of 3.34 and a standard deviation of 0.66. Finally, the question "The Credit management encourages training programs in credit risk management" was ranked with an average of 2.74 and a standard deviation of 0.70 .

There is an average level of use of Islamic banks and conventional banks for credit risk mitigation. The general average of 3.05 and the standard deviation was low of 0.52 . This indicates the convergence of opinions and the absence of large dispersion in the responses of the study sample members in credit departments in Lebanese banks about this variable.

\subsection{Test the Hypotheses of the Study}

For comparison between Islamic banks and conventional banks in credit risk management, the T-test was used for independent samples (Independent Sample T-Test). The rule of the decision, and acceptance of the hypothesis (H0) for the test, is to reject the null hypothesis and accept the alternative hypothesis (H1) if the calculated T-values are greater than the T-value of the scale at a level of 5\% (Malhotra, 2003). 


\subsubsection{First Hypothesis Test}

This hypothesis states that "There are no significant differences in understanding and awareness of credit risk between Islamic banks and conventional banks." To test this hypothesis, T was tested for independent samples (Independent Sample T-Test) and Table 8 shows the results of this test.

Table 8. Results of test analysis (T) to find differences in the level of awareness of credit risk

\begin{tabular}{llllll}
\hline & Mean & T-Calculated & T-Value & Sig level 0.05 & Statistical Decision \\
\hline Islamic Banks & 3.22 & 2.499 & 2.001 & 0.011 & Reject (H0) \\
Conventional Banks & 2.84 & & & & \\
\hline
\end{tabular}

It is clear from the previous table that the value of $(\mathrm{T})$ calculated is 2.499 while the value of the T-scale is (2.001). By comparing the values reached in the test of this hypothesis shows that the calculated value is greater than the value of the T-Scale, so we reject the null hypothesis (H0), which states that "there are significant differences at the level of significance (0.05) between Islamic banks and conventional banks in the level of understanding and awareness of credit risk". This is confirmed by the level of significance of (0.011) which is lower than 0.05 . The table also shows that the differences were in favor of Islamic banks with an average of 3.22, while the average for conventional banks is (2.84). That is, Islamic banks are more aware of credit risk than conventional banks. In the sense that Islamic banks are more understanding, aware and cautious in their approach than conventional banks.

\subsubsection{Second Hypothesis Test}

This hypothesis states that "There are no significant differences in credit risk assessment and analysis between Islamic banks and conventional banks." To test this hypothesis, $\mathrm{T}$ was tested for independent samples (Independent Sample T-Test) and Table 9 shows the results of this test.

Table 9. Results of test analysis (T) to find differences in the level of credit risk analysis

\begin{tabular}{lccccc}
\hline & Mean & T-Calculated & T-Value & Sig level (0.05) & Statistical Decision \\
\hline Islamic Banks & 3.43 & 3.461 & 2.001 & 0.001 & Reject (H0) \\
Conventional Banks & 2.88 & & & & \\
\hline
\end{tabular}

It is obvious from the table (9) that the value of $(\mathrm{T})$ calculated is 3.461 while the value of the T-scale is (2.001). By comparing the values reached in the test of this hypothesis shows that the calculated value is greater than the value of the T-Scale, so we reject the null hypothesis ( $\mathrm{H} 0)$, which states that "There are no statistically significant differences at the level of significance (0.05) in credit risk assessment and analysis between Islamic banks and conventional banks." This is confirmed by the level of significance of $(0.001)$ which is lower than 0.05 . The table also shows that the differences were in favor of Islamic banks with an average of 3.43, while the average for conventional banks is 2.88 . That is, Islamic banks are more aware of credit risk than conventional banks. In the sense that Islamic banks are more understanding, aware and cautious in their approach than conventional banks. Islamic banks are more efficient in assessing and analyzing credit risk than conventional banks.

\subsubsection{Third Hypothesis Test}

This hypothesis states that "There are no significant differences in the level of use of credit risk mitigation methods between Islamic banks and conventional banks." To test this hypothesis, $\mathrm{T}$ was tested for independent samples (Independent Sample T-Test) and Table 10 shows the results of this test.

Table 10. The results of the T-test analysis to find differences in the level of use of credit risk mitigation methods

\begin{tabular}{lccccc}
\hline & Mean & T-Calculated & T-Value & Sig level (0.05) & Statistical Decision \\
\hline Islamic Banks & 3.19 & 2.720 & 2.001 & 0.008 & Reject (H0) \\
Conventional Banks & 2.78 & & & & \\
\hline
\end{tabular}

It is clear from the previous table that the value of $(\mathrm{T})$ calculated is 2.720 while the value of the T-scale is (2.001). By comparing the values reached in the test of this hypothesis shows that the calculated value is greater than the 
value of the T-Scale, so we reject the null hypothesis (H0), which states that "There are no statistically significant differences at the level of significance $(0.05)$ in the level of use of credit risk mitigation methods between Islamic banks and conventional banks." This is confirmed by the level of significance of (0.008) which is lower than 0.05 . The table also shows that the differences were in favor of Islamic banks with an average of 3.19 , while the average for conventional banks is 2.78 . In other words, Islamic banks are more used to credit risk mitigation than traditional banks.

\section{Conclusions and Recommendations}

\subsection{Conclusions}

The objective of this study is to compare conventional and Islamic banks in various aspects of credit risk management processes. The study uses 200 questionnaires collected from 21 traditional banks and 4 Islamic banks in Lebanon. The results found that differences in the various issues of credit management between Islamic and conventional banks. Knowing that credit Risk is the most common risk that Islamic banks face, given that their operations dominated by debt-like transactions; Credit risk in Islamic banks is present in all types of debt-like transactions (i.e., murabaha, salam, istisna and ijara). In addition, profit and loss sharing (PLS) financing is beset with moral-hazard problems. Thus, Islamic financial institutions cannot profit from penalties imposed on debtors that have fallen into arrears and credit risk cannot be mitigated by the use of credit derivatives. Conventional banks on the other hand can charge interest as a condition for extending the maturity of the loan and credit derivatives are much widely available to conventional banks than to their Islamic competitors. For these reasons, Islamic banks are more understanding, awareness, and cautious in their approach than traditional banks. Islamic banks are more efficient in assessing and analyzing credit risk than conventional banks. All in all, Islamic banks are more used to credit risk mitigation than traditional banks.

\subsection{Recommendations}

The study recommended the need to create an appropriate environment to manage these risks in banks, especially traditional ones; by directing the boards to stimulate credit policy and strategy and senior management to implement it. Furthermore, the banks need to ensure the integrity of the process of providing and granting credit through the establishment of clear criteria for granting credit. Maintaining appropriate credit management for the credit portfolio in the light of measurement and monitoring and ensuring adequate risk control, is necessary.

To improve the quality of assets of conventional and Islamic banks, credit must be assessed objectively before and after it is granted, in addition to careful monitoring of client's accounts and regular monitoring of the borrower's project. Thus, banks should give due importance to properly applying credit monitoring and control mechanisms, and banks should also provide technical and advisory services to borrowers whenever required.

\section{References}

Aebi, V., Sabato, G., \& Schmid, M. (2013). Risk management, corporate governance, and bank performance in the financial crisis. Journal of Banking and Finance, 36.

Alam, M. Z., \& Masukujjaman, M. (2011). Risk Management Practices: A Critical Diagnosis of Some Selected Commercial Banks in Bangladesh. Journal of Business and Technology, 6(1).

Al-Tamimi, H. A. H., \& Al-Mazrooei, F. M. (2007). Banks' risk management: A comparison study of UAE national and foreign banks. The Journal of Risk Finance, 8(4).

Apostolik, R., Omar, A., Jachi, A., \& Izhar, H. (2015). The Islamic finance risk initiative. Global association of risk professionals (GARP) and Islamic research training institute (IRTI).

Bangladesh Bank. (2005). Managing core risks of financial institutions, credit risk management-industry best practice. Focus group on credit risk management, July.

Bo, H., Qing-Pu, Z., \& Yun-Quan, H. (2005). Research on Credit Risk Management of the State-Owned Commercial Bank. Proceedings of the Fourth International Conference on Machine Learning and Cybernetics.

Brown, B. M. (1998). Financial distress in local banks in Kenya, Uganda and Zambia: Causes and implications for regulatory policy. Development Policy Review Journal, 16(2).

Elgar, E. (2009). Islamic finance: Principles and practices. Edward Elgar publishing limited.

Ellul, A., \& Yerramilli, V. (2011). Strong risk controls, lower risk: Evidence from US bank holding companies. Working Paper, Indiana University. 
Gestel, T. V., \&Baesens, B. (2009). Credit Risk Management Basic Concepts: Financial risk components, rating analysis, models, economic and regulatory capital. New York: Oxford University press.

Greuning, H., \& Bratanovic, S. B. (2003). Analyzing and Managing Banking Risk: A Framework for Assessing Corporate Governance and Financial Risk (2nd ed.). The World Bank, Washington, DC. https://doi.org/10.1596/0-8213-5418-3

Gup, B. E., \& Kolari, J. W. (2005). Commercial banking-the management of risk (3rd ed.). John Wiley \& Sons.

Hakenes, H., \& Schnabel, I. (2010). Credit risk transfer and bank competition. Journal of Financial Intermediation, 19(3). https://doi.org/10.1016/j.jfi.2010.03.001

Hassan, A. (2009). Risk management practices of Islamic banks of Brunei Darussalam. The Journal of Risk Finance, 10(1). https://doi.org/10.1108/15265940910924472

Hennie, V. G. (2003). Analyzing and Managing Banking Risk: A Framework for Assessing Corporate Governance and Financial Risk (2nd ed.). Washington DC: World Bank Publications.

Hussain, A. H., \& Al-Ajmi, J. (2012). Risk management practices of conventional and Islamic banks in Bahrain. The Journal of Risk Finance, 13(3). https://doi.org/10.1108/15265941211229244

Ikbal, Z., \& Mirakhor, A. (2011). An introduction to Islamic finance: Theory and practice. Wiley finance. https://doi.org/10.1002/9781118390474

Khan, T., \& Ahmed, H. (2010). Risk Management: An Analysis of Issues In Islamic Financial Industry. Occasional Paper No. 5. Jeddah: Islamic Research and Training Institute, Islamic Development Bank.

Kraft, E., \& Jankov, L. (2005). Does speed kill? Lending booms and their consequences in Croatia. Journal of Banking \& Finance, 29(1). https://doi.org/10.1016/j.jbankfin.2004.06.025

Mileris, R. (2012). Macroeconomic Determinants of Loan portfolio Credit Risk in Banks. Engineering Economics, 23(5).

Ouamar, D. (2013). How to implement counterparty credit risk requirements under Basel III: The challenges. Journal of Risk Management in Financial Institutions, 6(3).

Richard, E., Chijoriga, M., Kaijage, E., Peterson, C., \& Bohman, H. (2008). Credit risk management system of a commercial bank in Tanzania. International Journal of Emerging Markets, 3(3). https://doi.org/10.1108/17468800810883729

Romanova, I. (2012). Bank Lending and Crisis: Case of Latvia. Journal of Business Management, 5.

Sekaran, U., \& Bougie, R. (2013). Research Methods for Business: A Skill-Building Approach. Wiley, New York.

Sujud, H., \& Hachem, B. (2017). Effect of Bank Innovations on Profitability and Return on Assets (ROA) of Commercial Banks in Lebanon. International Journal of Economics and Finance, 9(4). https://doi.org/10.5539/ijef.v9n4p35

Sujud, H., \& Hachem, B. (2018). Effect of mergers and acquisitions on performance of Lebanese banks. International Research Journal of Finance and Economis, (166).

Sundararajan, V., \& Errico, L. (2002). Islamic Financial Institutions and Products in the Global Financial System: Key Issues in Risk Management and Challenges Ahead. IMF working papers.

Tafri, H. F., Rahman, R. A., \& Omar, N. (2011). Empirical evidence on the risk management tools practiced in Islamic and conventional banks. Qualitative Research in Financial Markets, 3(2).

Venardos, A. (2006). Islamic banking and finance in south-east Asia: Its development and future. Singapore. World scientific publishing. https://doi.org/10.1142/6179

\section{Copyrights}

Copyright for this article is retained by the author(s), with first publication rights granted to the journal.

This is an open-access article distributed under the terms and conditions of the Creative Commons Attribution license (http://creativecommons.org/licenses/by/4.0/). 